$\mathrm{Nr} 6$

WARSZAWA-

KRAKÓW 2003

\title{
LECH PAKUŁA
}

Akademia Pedagogiczna, Kraków

\section{Tendencje restrukturyzacji przemysłu Górnośląskiego Okręgu Przemysłowego w dobie transformacji}

Transformacja systemu gospodarczego Polski - rozumiana dzisiaj jako proces - wymusiła i przyspieszyła w pewnym stopniu wiele innych procesów i zmian strukturalnych, w tym także restrukturyzację. Objęła ona nie tylko ważne działy produkcji, ale także wiele innych dziedzin życia społeczno-ekonomicznego, chociaż nadmierna interpretacja tego pojęcia i jego rozszerzanie powoduje skuteczne jego zamazywanie.

Procesowi restrukturyzacji podlegały w szczególności większe zakłady i całe gałęzie przemysłu w największym okręgu przemysłowym Polski, tj. w Górnośląskim Okręgu Przemysłowym. Celem opracowania jest więc ukazanie na tle zmian wielkości potencjału produkcyjnego GOP-u mechanizmów, zakresów i zaawansowania procesu restrukturyzacji, w szczególności wiodących w tym okręgu działów i gałęzi przemysłu surowcowego.

Aglomeracja GOP-u, jak dowodzi A. Szajnowska-Wysocka (1985), jest osobliwym fenomenem przemysłowym o burzliwej, ponaddwuwiekowej historii i pełnej obaw przyszłości.

Ten tradycyjny region przemysłowy o silnej strukturze menofunkcyjnej posiada współcześnie rozliczne problemy głównie natury ekonomicznej, społecznej i ekologicznej. Jest to $\mathrm{w}$ bieżącym stuleciu jeden $\mathrm{z}$ największych i najtrudniejszych regionów problemowych Europy, a patologiczny stan jego gospodarki, szczególnie przemysłu, jest w znacznym stopniu tworem prawie półwiecza gospodarki centralnie sterowanej (1945-1989). W okresie tym, jak stwierdza A. Klasik (1988), był to okręg przemysłowy, który dotarł do granic wzrostu i stał się w zasadzie regionem ,wzrostu bez rozwoju”.

Oznacza to, że Śląsk przez blisko pół wieku zbyt „zachłannie” kumulował środki inwestycyjne, pogłębiał swoją negatywną strukturę ekonomiczną będącą, jak dowodzi M. Tkocz (2001), „wynikiem monokulturowego modelu gospodarczego opartego na przemyśle wydobywczym i ciężkim”. Znikomy jest w tym okręgu udział przemysłów wysokich technologii i technikochłonnych, a więc przemysłów, które przyspieszają postęp gospodarczy i technologiczny, dynamizują rozwój, zmieniają niekorzystną strukturę aglomeracji regresywnych, do których niewątpliwie należy GOP. 
Według przybliżonych obliczeń przemysł nowoczesnych technologii, głównie samochodowy, elektroniki górniczej i obrabiarkowy zatrudnia 10 tys. osób (2000 r.), tj. ok. 3\% całości.

Na uwagę zasługuje jednak współczesna wielkość i zmiany całego potencjału produkcyjnego przemysłu GOP-u, które w tym okręgu stanowią o dynamice innych procesów gospodarczych, zmian strukturalnych i katastrofalnych skutkach degradacji środowiska.

Generalnie należy stwierdzić, że w niedługim okresie transformacji zmiany wielkościowe są ogromne, dostrzegalne nie tylko w strukturze przestrzennej, lecz także w ośrodkach przemysłowych i w miastach. Dobitnie ilustrują to nie tylko porównania liczbowe, ale także bezpośrednio kształt krajobrazu całych ośrodków miejsko-przemysłowych, a szczególnie fizjonomia starych dzielnic fabrycznych.

Aglomeracja ta zajmuje ciągle wyjątkową pozycję w życiu gospodarczym Polski i należy do większych okręgów przemysłowych Europy (Pakuła, Wicherek 1988). Aktualnie (2000 r.) znajduje tu pracę we wszystkich działach gospodarki, bez rolnictwa indywidualnego, 11\% ogółu pracujących w skali Polski, a więc niecały milion osób (907 tys.). Oznacza to jednocześnie spadek pracujących w stosunku do stanu maksymalnego sprzed okresu transformacji, o 760 tys. osób i obniżenie się wskaźnika udziału w kraju w minionym półwieczu (1950-2000) o 8\%. Proces zmian ogólnego zatrudnienia w gospodarce rzutuje nie tylko na znaczne zmniejszenie się zatrudnienia $\mathrm{w}$ przemyśle, ale przede wszystkim powstanie nie notowanego w historii tego okręgu bezrobocia. Wynosi ono obecnie (2000) 191 tys. osób, z czego kobiety stanowią 70\%, a region zaliczany jest do większego bezrobocia w Polsce.

Decydującą rolę w procesie wzrostu ekonomicznego tego okręgu i zatrudnienia w całej gospodarce odgrywa niezmiennie przemysł. Na ten dział gospodarki w okresie powojennym przypadało ponad połowa ogólnego zatrudnienia w regionie. Obecnie udział ten zmniejszył się do 46\% (2000) ogólnego zatrudnienia i systematycznie maleje. Wielkość ta w okresie powojennym w tym okręgu przekraczała znacznie średni wskaźnik dla Polski, maksymalnie o 21\%, lecz dzisiaj (2000) już tylko o 17\%. Zatrudnienie przemysłowe wynoszące w roku 2000 tylko 388 tys. osób, tj. 12\% w przemyśle Polski, zmalało w stosunku do stanu maksymalnego $\mathrm{z}$ początku lat osiemdziesiątych o blisko $0,5 \mathrm{mln}$ osób, lecz nadal przekracza potrzeby przemysłu tego okręgu.

Efekty ekonomiczne przemysłu tej przestarzałej aglomeracji, która ciągle koncentruje, obok dużego zatrudnienia przemysłowego, czwartą część potencjału w postaci środków trwałych, są niezadowalające i stanowią tylko 16\% (2000) wartości produkcji sprzedanej przemysłu Polski i są, po raz pierwszy w powojennej historii, o 4\% wyższe od zatrudnienia przemysłowego. Wielkości te są też potwierdzeniem powolnych, ale dostrzegalnych zmian surowcowego charakteru przemysłu tej aglomeracji, odbiciem jej rozwoju techniczno-innowacyjnego, ekonomicznego i strukturalnego, a także podejmowania produkcji droższej, bardziej nowoczesnej.

Rola tego okręgu przemysłowego w gospodarce Polski uwydatnia się jeszcze bardziej w produkcji szeregu wyrobów. Stąd w roku 2000 pochodziło: 96\% węgla kamiennego, całość wydobycia i produkcji cynku i ołowiu (wraz z częścią olkuską), 63\% stali surowej, prawie piąta część wytwarzanej energii elektrycznej w kraju, około $40 \%$ koksu, ale tylko $7 \%$ zamrażarek, 3\% obrabiarek, 6\% maszyn budowlanych, a więc wyrobów o wyższym stopniu przetwórstwa. Jedynie w produkcji samochodów osobowych Śląsk uczestniczy w kraju w 74\%. Jest to gałąź nowoczesna w tej aglomeracji, o krótkich tradycjach, która ciągnie technologicznie do przodu część przemysłu elektromaszynowego regionu. 
Ciągle jeszcze ogromna przewaga udziału GOP-u w produkcji krajowej przemysłów surowcowych, starych technologii, w dobie transformacji i globalizacji oraz przed wejściem Polski do Unii Europejskiej, pogłębia obawy o przyszłość tej aglomeracji.

Przedstawione wielkości udziałów GOP-u w ogólnopolskiej produkcji przemysłowej wskazują, że okręg ten nadal posiada tradycyjny charakter kompleksu węglowo-hutniczego, tym niemniej stanowi on rdzeń gospodarczy Polski, a przemysł jest tym działem, który wyznacza podstawową funkcję całej aglomeracji i odciska głębokie piętno na życiu człowieka oraz na efektywności ekonomicznej regionu (Pakuła 1996/1997).

W ścisłym związku z przedstawionym potencjałem produkcyjnym tego okręgu przemysłowego pozostają inne współczesne procesy tej aglomeracji, dynamika zmian i przebudowa strukturalna jego przemysłu.

Najbardziej znaczącym obok procesu prywatyzacji jest proces restrukturyzacji przemysłu, który stanowi jedyny na taką skalę przykład w kraju. Dotyczy to głównie centralnej części GOP-u określanej mianem Zespołu Miejskiego lub Aglomeracji Katowickiej. Szczególnie destrukcyjną rolę odgrywa tutaj wspomniany już kompleks węglowo-energetyczny i hutniczo-metalurgiczny.

W celu bardziej przejrzystego przedstawienia przebiegu zmian restrukturyzacji przemysłu w minionym dziesięcioleciu (1990-2000) przedstawię ją w układzie wspomnianych już dwóch kompleksów.

\section{KOMPLEKS PALIWOWO-ENERGETYCZNY}

\section{Górnictwo węglowe}

Proces restrukturyzacji posiada tutaj najszerszy zakres i najbardziej burzliwy przebieg. Uwzględniając wielorakie jej przejawy oddzielnie należy rozpatrzyć restrukturyzację techniczna, ekonomiczna, zatrudnienia i organizacyjna.

Strategia restrukturyzacji technicznej generalnie polegała, jak dotąd, nie tylko na przyspieszonym zamykaniu uciążliwych dla środowiska i nierentownych kopalń, lecz na ich technicznej przebudowie zmniejszającej negatywne oddziaływanie i deformację powierzchni ziemi, niszczenie zabudowy miejskiej oraz infrastruktury technicznej.

Górnictwo węglowe, o ponaddwuwiekowych tradycjach w tym okręgu, należy po II wojnie światowej do gałęzi wybitnie uprzywilejowanych (Kortus 1989), a dotacje państwowe, chociaż formalnie zniesione od 1992 roku, w różnej formie nadal wspierają deficytowe kopalnictwo. Efektem powojennych preferencji inwestycyjnych było wybudowanie 24 nowych kopalń węgla, z których 18 osiagnęło pełną zdolność produkcyjną. Są to kopalnie duże, dobrze zorganizowane i wyposażone technicznie, dysponujące automatyzacja procesów wydobywczych. Pozostałe około 20 starych kopalń (2002) także znacząco zostało przebudowane technicznie. Syntetycznym miernikiem restrukturyzacji technicznej w całym Zagłębiu Węglowym jest fakt, że urabianie węgla w obudowie zmechanizowanej wynosi obecnie $85 \%$, ładowanie mechaniczne $82 \%$, a transport zmechanizowany $100 \%$. 
Zakres restrukturyzacji technicznej nasilił się zwłaszcza po 1980 roku, odkąd prawie wszystkie kopalnie, stare i nowe, uzyskały nowoczesne maszyny wyciągowe (skipy) i urządzenia wentylacyjne oraz łaźnie, a większość urządzenia do podsadzki płynnej, celem zapełnienia pustych przestrzeni po wydobytym węglu. Umożliwia to jego eksploatację z dawnych filarów ochronnych pod zabudowę miejską i przemysłową. Z filarów ochronnych pochodzi ciągle około $1 / 3$ wydobywanego w Zagłębiu węgla, bowiem można go tam łatwo i - co dzisiaj istotne - niedrogo pozyskać. W ostatnim dziesięcioleciu (1990-2000) znacznie jednak zmniejszono stosowanie tej podsadzki, z 44\% w latach siedemdziesiątych do $4,4 \%$ w roku 2000, szukając oszczędności dla ciągle nierentownej eksploatacji węgla. Katastrofalne skutki tych ograniczeń widoczne są głównie w postaci różnorodnych form antropogenicznych na powierzchni ziemi, obecnie głównie wklęsłych.

Przechodząc do oceny restrukturyzacji ekonomicznej, należy podkreślić, że górnictwo górnośląskie mimo tak wielkiej i udanej przebudowy technicznej ciągle nie dorównuje efektywnością górnictwu amerykańskiemu, południowoafrykańskiemu czy też australijskiemu. Koszty jednostkowe wydobycia tony (2001 r. - około 32\$) węgla górnośląskiego są kilka razy większe niż u wspomnianych producentów zagranicznych. Poważny wpływ na wynik ekonomiczny ma wydajność pracy, która wprawdzie szybciej wzrasta od założeń w dobie transformacji, tj. z 492 ton/pracownika w roku 1995 do 725 w 2001 r., lecz ciągle nie dorównuje średniej w górnictwie zachodnim wynoszącej 1 tys. ton. Wydaje się, że szczególnie mocno obciąża tę wydajność nadmiar pracowników administracyjno-technicznych, o czym świadczyć może 50\% różnica między wydajnością (2001) dołową wynoszącą 7,2 tony/robotnikodniówkę, a ogólną liczoną na procownikodniówkę w ilości 3,6 tony.

Górnictwo węglowe przez cały okres gospodarki planowanej centralnie było deficytowe, podobnie jak w minionym dziesięcioleciu (1990-2000) transformacji. Liczba kopalń $\mathrm{z}$ akumulacją dodatnią od początku lat dziewięćdziesiątych zmieniała się, lecz nie przekraczała 40\% wszystkich. Do każdej tony węgla kopalnie - budżet państwa - dopłacały od 15 zł w 1995 do 22,6 zł w 1998 i 13,10 zł w1999 r. Każda też tona węgla wyeksportowanego była o 20 zł niższa (1995 - 32,3 mln ton) od krajowej, ale wysoki i nieopłacalny eksport pozwolił na utrzymanie przerostu zatrudnienia o $20 \%$ wbrew logice ekonomicznej. Jeszcze obecnie (2002 r.) 80\% wyeksportowanego węgla, tj. ok. $18 \mathrm{mln}$ ton sprzedawane jest poniżej kosztów wydobycia, a w programie restrukturyzacji do roku 2006 przewiduje się utrzymanie niższych cen od krajowych nawet o $8 \%$.

W tych okolicznościach ekonomicznych narastało ogromne zadłużenie górnictwa węglowego względem państwa sięgające na koniec 2002 roku 20,5 mld zł, a więc o prawie $62 \%$ więcej w stosunku do roku 1995. Najbardziej zadłużone jest górnictwo względem ZUS - ok. $43 \%$, różnego szczebla samorządom zalega $22 \%$, budżetowi państwa $18 \%$, a na rzecz ochrony środowiska ok. 13\%. Zadłużenie to ma zniwelować specjalny program rządowy umorzeniowo-odroczeniowy, zwłaszcza że górnictwo górnośląskie od roku 2000 staje się rentowne. Zysk na każdej tonie węgla wyniósł w roku 2000 - 2,37 zł (całość 187 mln zł), w 2001 roku 7,04 zł (725 mln zł).

Efekty ekonomiczne ostatnich dwóch lat są rezultatem wieloetapowej i bardzo konsekwentnej restrukturyzacji tej branży, w której na plan pierwszy przez minione dziesięć lat wysuwa się problem restrukturyzacji zatrudnienia. Dowodzi tego wysoki udział kosztów pracy (ceny bieżące) w kosztach jednostkowych wydobycia tony węgla, które wprawdzie spadły w dobie transformacji o około 7\%, lecz koszty robocizny sięgają ciagle (2001) połowy kosztów wydobycia. 
Mimo zwolnienia w kopalniach węgla w dobie transformacji (1989-2002) 273 tys. górników, tj. około $66 \%$ stanu maksymalnego z końca lat osiemdziesiątych, zatrudnienie wynosi jeszcze ok. 141 tys. osób, a w ramach dalszego programu restrukturyzacji przewiduje się do roku 2006 redukcję o kolejne 35 tys. etatów. Mimo to górnictwo górnośląskie pozostanie i tak w całej Unii Europejskiej największym skupiskiem ludzi pracujących w węglu kamiennym. Pojawia się pytanie, jakie przyjać mechanizmy, jak odciagnąć górnika w ramach restrukturyzacji do innych branż lub działów gospodarki narodowej. Silnie przyciaga go do tej pracy wysoka, jak na polskie warunki, pensja, która wzrosła w latach 1995-2000 2,3-krotnie, tj. z 1,4 do 3,3 tys. zł (średnia brutto) i to bez jakiegokolwiek związku z sytuacją ekonomiczną kopalń. Należy jednak mieć na uwadze, że praca górnika jest ciężka i brudna, niebezpieczna dla życia i przez cały okres transformacji ciąży nad nim widmo zwolnień grupowych. Mimo że w dotychczasowych programach restrukturyzacji górnictwa nie udało się zmniejszać zatrudnienia bezkonfliktowo, to najłagodniej proces ten przebiegał w minionym czteroleciu (1998-2001). Na sto tysięcy zwolnionych osób, aż 2/3 skorzystało z instrumentów osłonowych i aktywizujących Górniczego Pakietu Socjalnego, a więc o $8 \%$ więcej niż przewidywał program. Bardzo zachęcające były jednorazowe, bezwarunkowe odprawy pieniężne w wysokości 50, a nawet 70 tys. zł (brutto), z których skorzystało ok.

33 tys. górników.

Tak więc proces restrukturyzacji zatrudnienia w górnictwie węglowym, chociaż przebiega boleśnie i z oporami społecznymi, prowadzi powoli górnictwo węglowe do rentowności. Należy zauważyć, że zmniejsza się też krajowe zapotrzebowanie na węgiel kamienny, którego wydobycie spadło w latach 1988-2001 o $90 \mathrm{mln}$ ton (ze 193 do $103 \mathrm{mln}$ ton). Przewiduje się do roku 2006 dalsze zmniejszenie wydobycia o 12,5 mln ton, co - jak należy sądzić - łączy się głównie z bardzo nieopłacalnym eksportem. Tego typu perspektywy powoduja dzisiaj bardzo liczne strajki, manifestacje oraz dyskusje nad kolejnym programem restrukturyzacji górnictwa i jego organizacyjnym kształtem.

Istotną dla realizacji reformy górnictwa jest również restrukturyzacja organizacyjna. Od roku 1993, po likwidacji dawnych zjednoczeń, których istotą była centralizacja zarządzania, kopalnictwo działało w ramach sześciu spółek weglowych i Holdingu Katowickiego. Początkowo nie obejmowały one wszystkich kopalń (np. „Jan Kanty” „Żory”, „Budryk”), lecz przyczyniły się do większej samodzielności ich działania. Spółki te jeszcze z początkiem 2003 roku grupowały 41 kopalń czynnych i 13 w likwidacji oraz 42 inne jednostki organizacyjne, głównie usługowe, transportowe i agencje, m.in. ubezpieczeniowe i turystyczne. Nadto działa samodzielna kopalnia „Budryk”, objęta próbami prywatyzacji. Na uwagę zasługuje też przekształcenie (1998) Państwowej Agencji Węgla Kamiennego w Państwową Agencję Restrukturyzacji Górnictwa (PARG) i powierzenie jej bezpośrednio wszystkich zadań nad przebiegiem zmian strukturalnych tej branży.

Ogólnie należy stwierdzić, że ciagła zmienność organizacyjna zarządzania górnictwem węglowym Górnego Śląska i brak dłuższej stabilizacji nie sprzyja efektywności działania tej branży.

W scenariuszu radykalnym lub umiarkowanym, który ostateczną formę przybierze w latach 2003-2006, w stan upadłości ma być poddane 5 Spółek Węglowych, grupujących 24 kopalnie, przy założeniu likwidacji 5 lub $6 \mathrm{z}$ nich. Pozostawione kopalnie z dawnych spółek: Bytomskiej, Gliwickiej, Nadwiślańskiej, Rudzkiej i Rybnickiej weszłyby do nowo utworzonej Kompanii Węglowej, po czym następowałaby stopniowa ich sprzedaż. Pozosta- 
łe dwie spółki, tj. Jastrzębska i Holding Katowicki skupiłyby 12 kopalń i przetrwały zarówno w wariancie radykalnym, jak i umiarkowanym.

Oceniając różnorodne zakresy restrukturyzacji górnośląskiego górnictwa węglowego należy podkreślić, że restrukturyzację techniczną i zatrudnienia uznać należy za prawidłową i zadowalająca, a najbliższą trzyletnią perspektywę za obiecująca, o ile nie zostanie zakłócona rozruchami społecznymi. Restrukturyzacja ekonomiczna ciagle nie daje spodziewanych efektów, chociaż ostatnio pojawiło się światło nadziei.

Najgorzej przebiega restrukturyzacja organizacyjna, którą ciągle silnie steruje dobrze płatne lobby górnicze. Grupa ta partykularnie broni swoich interesów, co wskutek częstej zmienności organizacji i zarządzania górnictwem nie zapewnia dobrego funkcjonowania spółek i poszczególnych kopalń.

\section{Koksownictwo}

Rozwój koksownictwa w aglomeracji górnośląskiej datuje się na przełomie XIX i XX stulecia. Był to przez cały niemal wiek XX jeden z najbardziej uciążliwych i brudnych przemysłów, o ogromnej szkodliwości dla środowiska. Trzynaście istniejących jeszcze przed okresem transformacji koksowni przykopalnianych i przyhutniczych to zakłady o bardzo przestarzałej technologii, małej wydajności i ogromnej uciążliwości dla miast i zamieszkałej w nich ludności. Restrukturyzacja polega głównie na stopniowym zamykaniu tych koksowni w miastach zachodniej cześci GOP-u, a ostatnio w Czerwionce. Spośród 35 starych baterii koksowniczych posiadających 1050 komór, w roku 2000 pracowało ich jeszcze tylko około $15 \%$. Oznacza to, że produkcję podtrzymują dwie baterie starej koksowni w Knurowie i bardzo przebudowana technologicznie koksownia w Radlinie.

Jednocześnie wraz z upadkiem przestarzałego technologicznie koksownictwa górnośląskiego rozpoczął się proces jego przebudowy. Łączy się to z uruchomieniem w roku 1987 w Dąbrowie Górniczej wielkiej, nowoczesnej i przyjaznej środowisku i mieszkańcom koksowni przy hucie „Katowice”. Jest to zakład o czterech bateriach wielkokomorowych, co odpowiada 240 komorom tradycyjnym i rocznej produkcji $2,8 \mathrm{mln}$ ton koksu. Jej wyższość technologiczna w stosunku do starych koksowni, oprócz wydajności, polega na tym, że emituje ona do atmosfery pięciokrotnie mniej pyłów i węglowodorów oraz dziesięciokrotnie mniej siarkowodoru i fenolu.

\section{Energetyka}

Zamknięcie rozważań nad restrukturyzacją przemysłów związanych z węglem w aglo-meracji GOP-u wymaga też rozpatrzenia kwestii energetyki. Restrukturyzacja techniczna energetyki polegała głównie na zamknięciu ok. 22 starych, technologicznie mało sprawnych, nieekonomicznych i uciażliwych dla środowiska elektrowni przykopalnianych, przyhutniczych i przyzakładowych. W ich miejsce wybudowano po II wojnie światowej 8 dużych elektrowni zawodowych, o łącznej mocy ok. 6 tys. MW, dzięki czemu GOP jest nadal „kręgosłupem energetycznym” Polski. Elektrownie te mimo wielkiego postępu technicznego i opanowania zapylenia, w dalszym ciagu powodują ponad $60 \%$ wszelkich zanie- 
czyszczeń w omawianej aglomeracji - głównie dwutlenkiem siarki. Walka z siarką jest w tym okręgu ogromna i zaczyna się współcześnie już na etapie wydobycia i przeróbki węgla w kopalniach, bowiem każda tona węgla zawiera średnio 0,77\% siarki (ok. $8 \mathrm{~kg}$ ). Następny etap odbywa się już w samej elektrowni i oparty jest na doświadczalnej instalacji polskiej (NID). To powoduje i tak, że zanieczyszczenie dwutlenkiem siarki aglomeracji górnośląskiej jest obecnie (2000) jeszcze 4-krotnie większe niż na początku ubiegłego wieku, ale

w latach osiemdziesiątych było 25 -krotnie wyższe. Jest też wiele innych działań na rzecz ochrony środowiska, m.in. ograniczających emisję związków azotu (170 g/GI) oraz lokowania popiołu ze spalanego węgla w podziemiach kopalń. Energetyka staje się powoli przyjazna środowisku.

\section{KOMPLEKS HUTNICZO-METALURGICZNY}

\section{Hutnictwo żelaza}

Hutnictwo wielkopiecowe mimo dwuwiekowej tradycji rozwojowej na Górnym Śląsku, cechowało do czasu transformacji duże opóźnienie technologiczne. Powojenne wysiłki państwa skierowane były głównie na ilościowy wzrost produkcji, wydajność i wielkogabarytowość.

Do roku 2000 zlikwidowano 85\% wielkich pieców funkcjonujących jeszcze u progu transformacji (1989). Przemysł ten powodował bowiem ok. 20\% zanieczyszczeń pyłowo-gazowych całej aglomeracji. Wytop surówki, a więc wielkie piece, usunięte zostały w Chorzowie, Bytomiu i Rudzie Śląskiej, a wcześniej w Świętochłowicach i Zawierciu. Ogromne znaczenie dla czystości środowiska miało też usunięcie kilkudziesięciu obiektów i urządzeń wspomagających hutnictwo surowcowe, m.in. czadnic do wytwarzania gazu, wytrawiania w kwasie siarkowym, przerobu zgarów i wielu innych. Prawie cała część surowcowa hutnictwa przeniesiona została na skraj Zespołu Miejskiego do Huty Katowice w Dąbrowie Górniczej, gdzie po roku 1976 wybudowano 3 wielkie piece o pojemności 3,2 tys. $\mathrm{m}^{3}$ każdy. Warto podkreślić, że przeniesienie części surowcowej stało się realne dopiero $\mathrm{w}$ dobie transformacji i wielkich przemian społeczno-ekonomicznych po roku 1990.

Rewolucyjnej przebudowie uległa też druga część produkcji surowcowej - stalownictwo oparte na starej XIX-wiecznej technologii martenowskiej. Do roku 2000 zamknięto ok. 36 pieców stalowniczych, tj. prawie $80 \%$ wszystkich, opartych na starej technologii. Większość stalowni martenowskich unieruchomiono w tzw. trójkącie śmierci, a więc Chorzowie, Bytomiu i Rudzie Śląskiej, nadto w Katowicach, Gliwicach i Sosnowcu. Jednocześnie zbudowano (1978-1980) nowoczesne stalownie konwertorowo-tlenowe w Hucie Katowice, o 30-krotnie większej sprawności produkcyjnej od starych i bezpieczne dla środowiska. Uruchomiono też kilka stalowni elektrycznych, m.in. w Łabędach-Gliwicach, Sosnowcu i Łaziskach.

Proces przebudowy hutnictwa trwa, wymaga jednak pieniędzy i czasu. Wejście Polski do Unii Europejskiej w 2004 roku proces ten przyspieszy, jak również wzmoże inne dzia- 
łania. Już obecnie bowiem (2002) zauważa się symptomy pewnej organizacyjnej integracji, a wkrótce prywatyzacji i tendencji globalizacyjnych. Z końcem 2002 roku powstał koncern stalowy „Polskie Huty Stali”. W skład tego koncernu weszły huty: „Katowice” w Dąbrowie Górniczej, „Sędzimira” w Krakowie, „Cedlera” w Sosnowcu i „Florian” w Świętochłowicach. Skonsolidowane polskie huty, skupiając łącznie około 75\% zdolności produkcyjnych polskiego hutnictwa żelaza, mają wielką szansę na dodatnią rentowność i racjonalizację swojej działalności. Już kilka wielkich międzynarodowych koncernów, m.in. amerykański US Steel, międzynarodowy LNM, francusko-niemiecki Arcelor i niemiecki Thyssen Krupp, wykazało zainteresowanie koncernem stalowym Polski.

\section{Hutnictwo cynkowo-ołowiane}

Restrukturyzacja w hutnictwie cynkowo-ołowiowym GOP-u miała charakter wybitnie technologiczny i polegała po roku 1980 na całkowitej eliminacji piecowego wytopu cynku i ołowiu w hutach Świętochłowic (Lipiny) i Katowic (Szopienice, Wełnowiec) oraz przekształceniu procesu wytopu za pomoca elektrolizy. Piecowy, stary technologicznie, wytop cynku przy pomocy koksiku, w setkach małych pieców zwanych ,tyglami”, w 80 niewielkich hutach funkcjonujących na tym obszarze w różnych okresach XIX i XX wieku, powodował silne zatruwanie środowiska, głównie wyziewami dwutlenku siarki, azotu i kadmu oraz innymi bardzo szkodliwymi dla człowieka pierwiastkami chemicznymi.

Do przebudowanych technologicznie na elektrolizę starych hut cynku dołączyły po II wojnie światowej dwie nowocześniejsze wybudowane w Bukownie k/Olkusza (1954 r.) i Miasteczku Śląskim k/Tarnowskich Gór (1968 r.). Unieruchomiono jednocześnie bardzo szkodliwe dla otoczenia wydziały wspomagające, m.in. baterie czadnic i wydział kwasu siarkowego w Miasteczku Śląskim, piece spiekalnicze w Piekarach Śl., Bukownie i Szopienicach. Zaprzestano też całkowicie wydobycia rud cynku i ołowiu w Niecce Bytomskiej, a całe kopalnictwo przeniosło się w rejon Olkusza.

Przemysł cynkowy należał w aglomeracji GOP-u, obok koksownictwa, do najbardziej brudnych i szkodliwych dla środowiska.

Podsumowując analizę procesu restrukturyzacji tego potężnego okręgu przemysłowego należy podkreślić, że na około 90 przebudowanych i zamkniętych większych zakładów i wydziałów, ponad 80\% należało do kompleksu paliwowo-energetycznego i metalurgicznego, a rewitalizacja obszarów zniszczonych i zdegradowanych zaczyna powoli być widoczna i odczuwalna przez ludzi i przyrodę.

\section{Literatura}

Klasik A., 1988, Restrukturyzacja regionu katowickiego, Studia nad ekonomiką regionu, Nr 23

Kortus B., 1989, Die Agglomerationen von Oberschlesien und Krakau als Problemgebiete, [w:] Sozialgeographische Probleme der Agglomerationen von Krakau und Oberschlesien, red. H. Förster, B. Kortus, Bochumer Geographische Arbeiten, 51, s. 1-9

Pakuła L., Wicherek S., 1988, Les principaux problemes actuels des agglomerations industrielles de Haute Silesie et leurs influences sur le milieu, Annales der Geographie 543

Pakuła L., 1996, 1997, Der Oberschlesische Industriebezirk. Zur Entwiclung und zum Strukturellen Wandl der Industrie innerhalb der Agglomeration, „Zeitschritt für den Erdkundeunterricht”, $12 / 1996$ i $1 / 1997$ 
Tkocz M., 1998, Wybrane aspekty restrukturyzacji górnictwa węgla kamiennego, [w:] Geographia. Studia Dissertationes, t. 22, red. T. Szczypek, Katowice, s. 108-129

Tkocz M., 2001, Restrukturyzacja przemystu regionu tradycyjnego, Katowice

Szajnowska-Wysocka A., 1985, Wspótczesne bariery rozwojowe aglomeracji górnoślaskiej, „Czasopismo Geograficzne", 56, 3-4, s. 295-296 